Available online at GSC Online Press Directory

GSC Biological and Pharmaceutical Sciences

(RESEARCH ARTICLE)

\title{
In vitro callus induction and indirect organogenesis of Mentha piperita (L.) - an aromatic medicinal plant
}

\author{
Islam A. T. M. R. ${ }^{1,}$ and Alam M. F. ${ }^{2}$ \\ ${ }^{1}$ Department of Botany, Faculty of Bio-Sciences, University of Barisal, Barisal-8200, Bangladesh. \\ 2 Department of Botany, University of Rajshahi, Rajshahi-6025, Bangladesh.
}

Publication history: Received on 10 August 2018; revised on 24 August 2018; accepted on 27 August

2018 Article DOI: https://doi.org/10.30574/gscbps.2018.4.3.0078

\begin{abstract}
The effect of different concentrations and combinations of plant growth regulators were tested for in vitro callus induction and indirect plant regeneration of Mentha piperita L. from young leaves and internodal explants. Greenish, organogenic and nodular nature of callus was achieved only from leaf disc explant when cultured on MS medium containing $1.5 \mathrm{mg} / \mathrm{l} \mathrm{NAA}+0.2 \mathrm{mg} / \mathrm{l} \mathrm{BAP}$ and then subsequent plant regeneration was obtained on MS medium supplemented with $2.0 \mathrm{mg} / \mathrm{l} \mathrm{BAP}+0.5 \mathrm{mg} / \mathrm{l}$ NAA from leaf derived callus. The highest frequency of shoot regeneration $(90 \%)$ with the maximum number of shoots $(15.1 \pm 0.11)$ was achieved in this medium. In vitro raised microshoots showed $90 \%$ response with maximum number of roots $(16.3 \pm 0.23)$ on $1.0 \mathrm{mg} / \mathrm{l}$ IBA after $11-12$ days. Then in vitro rooted plantlets were move to polybags bearing soil and vermiculite mixture in 1:1 ratio for hardening and hardened plantlets showed $95 \%$ survivability on field conditions.
\end{abstract}

Keywords: In vitro; Callus induction; Organogenesis; Mentha piperita; Vermiculite

\section{Abbreviations}

NAA $=\alpha$-Naphthalene acetic acid; 2, 4-D = 2, 4-Dichlorophenoxyacetic acid; IAA = 3-Indole acetic acid; BAP = 6Benzylaminopurine; $\mathrm{Kn}=$ Kinetin and IBA = 3-Indole butyric acid.

\section{Introduction}

Medicinal plants have long been used for health care purpose throughout the world since ancient times by Ayurvedic, Unani, and the folk medicinal systems and still are extensively using as remedies in modern remedial practices for its powerful medicinal properties [1]. Archaeological evidences revealed that, peppermint (Mentha piperita L.) is the world's oldest medicine used since at least ten thousand years ago [2].

Mentha piperita L. is supposed to be a sterile natural hybrid of M. aquatica $(2 n=96)$ and M. spicata $(2 n=48)$ belonging to limiaceae family which is allohexaploid $(2 n=72)$ [3]. Mentha piperita is found as a perennial plant grown all countries around the world and seen as both wild and cultivated, and might be proliferated by vegetative and reproductive means in nature [4]. The family members of limiaceae have a big pharmacological and commercial importance. $M$. piperita and M. arvensis leaves have been usually used for obtaining peppermint oil that is widely used for the manufacturing of commercial products such as shampoo, chewing gum, toothpaste, ice cream, soap, tea and more [5].

\footnotetext{
${ }^{*}$ Corresponding author

E-mail address: atmrislam@barisaluniv.ac.bd
}

Copyright (C) 2018 Author(s) retain the copyright of this article. This article is published under the terms of the Creative Commons Attribution Liscense 4.0. 
Peppermint essential oils e.g. Limonene, cineol, polygon, piperitone have a natural antibacterial, antiviral, anti-fungal, anti-parasitic, analgesic (pain reliever), insecticidal, immuno modulating and anti-aging properties [6-8]. According to German Commission E monographs [9] peppermint oil has also been used internally and externally e.g. to treat irritable bowel syndrome, as an antispasmodic (upper gastrointestinal tract and bile ducts), inflammation of the oral mucosa, catarrh of the respiratory tract, and for myalgia and neuralgia.

There have few problems for improvement of Mentha species by sexual crosses of conventional breeding methods. In this case, conventional breeding approaches are often difficult even unsuccessful because of its high ploidy number and pollen sterility problems. It has been demonstrated in one previous report that only six viable seeds have produce after fertilization whereas 18,000 peppermints floral spikes bearing more than 2.75 million ovules $[1,10]$.

Therefore, in vitro technique might be a useful method for huge amount production of disease free plantlets of $M$. piparita for manufacture of drug and other industrially valuable products. Moreover, this method could be a potential tool for creating genetic diversity in peppermint genotypes by inducing somaclonal variation, construction of somatic hybrids and creation of transgenic plants [11]. For this, firstly requires developing a reliable plant regeneration protocol under least cost to applied plant biotechnology in the development of Mentha species [1]. In this case, plant tissue culture technology such as in vitro callus induction and subsequent plant regeneration from callus tissue could be a very functional and promising technology to overcome the problem and can play a very important role in the rapid mass proliferation, secondary metabolite production, new germplasm generation and conservation, and overall potential use of this plant. Moreover, in vitro mutant selection, genetic improvement at cellular level and understanding the stress physiology of cell can be achieved by callus culture. In vitro callus induction and indirect plant regeneration by plant growth regulators (PGRs) accelerate the proliferation of plantlets all over the year overcoming the seasonal barrier [12].

Previously, a number of investigator have been efficiently cultured Mentha piperita [1, 2, 13-21], and other species of mint including M. viridis [22-24], M. spicata [25, 26], M. pulegium, M. suaveolens, and M. arvensis in vitro using shoot tip, node, leaf disc, inter node, and other propagule as explants following organogenesis or callogenesis on MS medium [27] either presence or absence of plant growth regulators. But limited studies were attempted specifically on in vitro callus induction and indirect plant regeneration via callus culture of peppermint. Therefore, the present investigations were attempted to develop a unique, clear, simple and reliable protocol with aims and objectives to a fast, suitable regeneration protocol of $M$. piperita via callus culture that make sure high frequency of regeneration and high survival rate of plants after acclimatization within a short time in view of high medicinal value and increased demand in the pharmaceutical industry of this plant.

\section{Material and methods}

\subsection{Plant material}

Young leaf and internodal segments from in vitro developed plantlets were used as explants in this experiment which are excised from the previously micropropagated shoots of M. piperita. Intended for micropropagtion, Mentha piperita plants were obtained from Medicinal Village of Natore, Bangladesh (this works were carried out by same authors in their earlier experiment).

\subsection{Surface sterilization}

Since in the present study, in vitro developed plant materials were directly used as explants source, so, there is no need to surface sterilize the plant material. However, primary explants (Shoot tips and nodal segments) used for micropropagtion in earlier experiment of the authors was washed about 30 minutes under tap water and then cleaned with a mild liquid detergent solution for $5 \mathrm{~min}$. and a quick wash in $70 \%$ alcohol for disinfection. Surface sterilization was finished by $0.1 \% \mathrm{HgCl}_{2}$ solution for 3-5 $\mathrm{min}$. and finally 3-4 times washings were carried out by double distilled water.

\subsection{Outline of the experiment}

Three phase regeneration systems were followed for carrying out the present experiment. In first stage, callus formation was induced from explant sources. In second stage, de novo shoot proliferation was enhanced from callus tissues and in third and final stage; root initiation of proliferated shoots was achieved and then successfully acclimatization of regenerated plantlets to ex vitro conditions were done. 


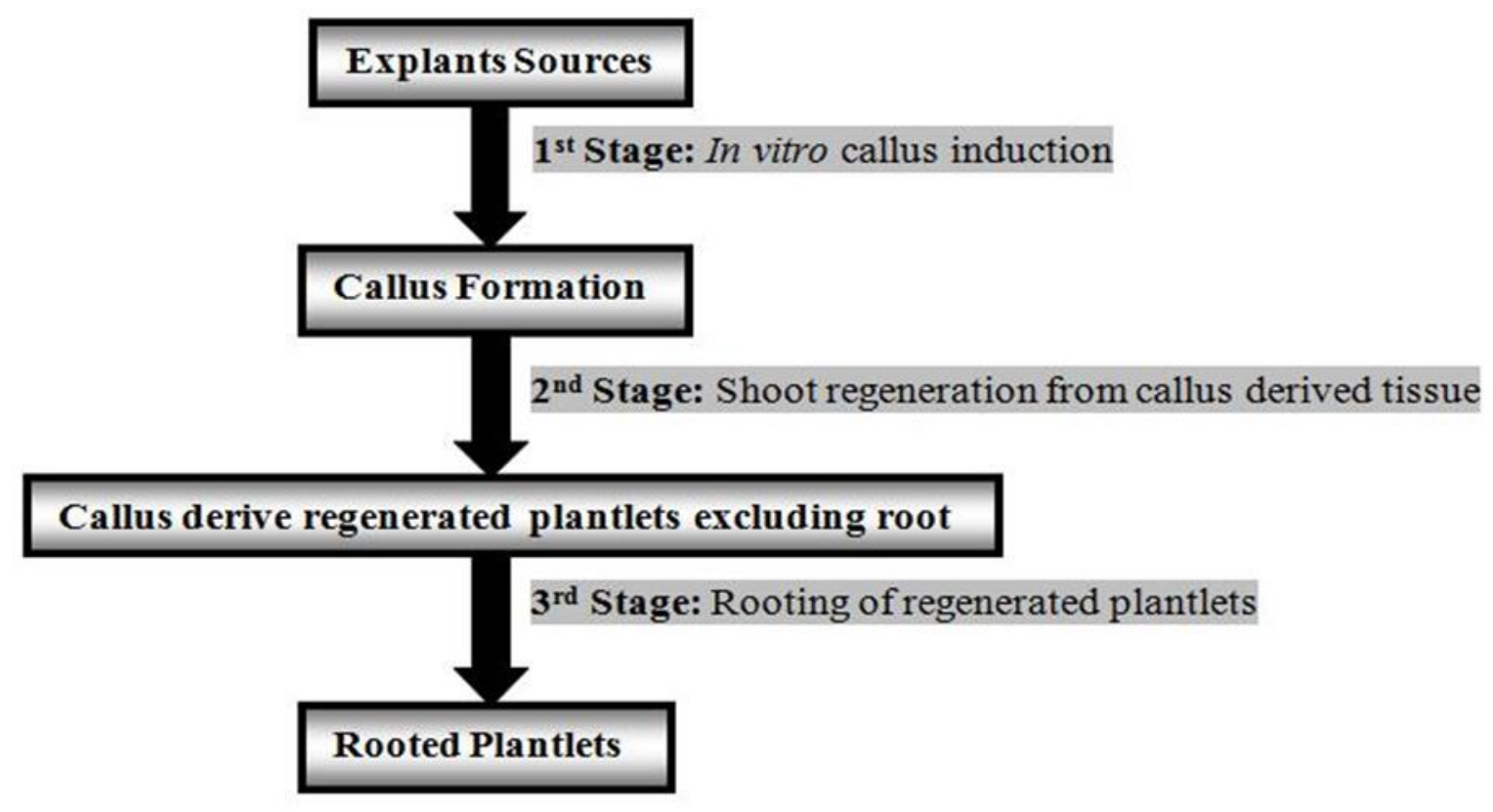

Figure 1 Schematic representation of in vitro procedure of callus induction and subsequent plant regeneration

\subsection{Culture medium, culture conditions and sub culturing}

The explants were cultured on MS [27] supplemented $0.8 \%$ (w/v) agar medium containing different types of auxins mentioned as NAA, 2, 4-D and IAA in various concentrations and combination with various types of cytokinins like as BAP and Kn for callus induction. The cultures were further subcultured by routine intervals of 14 days on fresh medium for in vitro enhancing of shoot proliferation and root initiation. In this case, different concentrations and combination of cytokinin and auxins ratio were used for in vitro shooting and rooting from callus tissue. The pH of the medium was adjusted to 5.8 before autoclaving at $121^{\circ} \mathrm{C}$ and $1.06 \mathrm{~kg} / \mathrm{cm}^{2}$ pressure for $20 \mathrm{~min}$. The cultures were maintained in a growth chamber at $25 \pm 2^{\circ} \mathrm{C}$ for first 3 days in dark and then transferred to $16 \mathrm{~h}$ photoperiod (cool, white fluorescent light with 3000 lux light intensity) with $50-70 \%$ relative humidity.

\subsection{Observed parameters}

Callus formation quantity, callus texture and colour, callus induction period, callus induction frequency (\%), callus diameter $(\mathrm{cm})$ and weight $(\mathrm{gm})$ were the observed parameters for callus induction experiment. Callus induction frequency was calculated by implementing the following formula-

$$
\text { Callusinductionfrequency }(\%)=\frac{\text { No. of explants produced calli }}{\text { No. of explants cultured }} \times 100
$$

In shoot proliferation experiment, the observed parameters were shoot proliferation percentage (\%), shoot induction period, shoot length $(\mathrm{cm})$ and shoot number and number of nodes and leaves. Moreover, root emerging frequency (\%), root initiating period, root number and root length $(\mathrm{cm})$ were also the observed parameters for root initiation experiment.

\subsection{Statistical analysis}

All statistical analyses were done followed by one-way ANOVA using DMRT Test $(\mathrm{P}<0.05)$ and data were presented as the mean \pm standard error (SE). A minimum of 20 explants were cultured in each experiment and all treatments were recurring at least three times.

\section{Results and discussion}

\subsection{Callus induction}

In vitro grown juvenile leaf and internodal segments of Mentha piperita were inoculated on MS supplemented different types of auxin growth regulators like NAA, 2, 4-D and IAA with cytokinin namely BAP and Kn at various concentrations 
and combinations for callus induction. Callus tissues were initiated within 10-15 days of culture from both explants and show a degree of differential response to separate ratio of plant growth regulators (Table-1 \& Figure-2). Type of response was relying on both explants and plant growth regulators supplements to the medium. Although, callus induction was achieved from both explants types, however, leaf disc explants showed better performance as explant source than internodal segments for callus induction. This result indicates that different types of explants contain varying levels of endogenous auxin concentrations and callus induction ability is determined by their endogenous hormone variability [28]. It is mentioning that callus formation was not observed on MS control medium. The intensity of callus induction and percentage of response was significantly influenced by the type of explants source and plant growth regulators.

\subsection{Effect of auxin and cytokinin combination ratio on callus induction}

Previous studies [2] describe that in vitro callus stimulation and successive plantlet regeneration in Mentha piperita need the presence of proper amount and different concentrations of auxins and cytokonins either singly or in combined with each other in MS medium. Although, theoretically it has been said that equal amount of auxin and cytokinin promote callus stimulation but in practice, a huge level of variation was observed due to variations of phytohormones in the endogenous levels of individual plants $[12,29,30]$.

\subsection{Effect of NAA, 2, 4-D and IAA in combination with BAP on callus induction from leaf disc and internodal explants}

Leaf disc and internodal explants were inoculated on MS medium containing NAA, 2, 4-D and IAA with combination of BAP at various concentration (0.5- $2.0 \mathrm{mg} / \mathrm{l}$ ) for callus induction. Callus induction was achieved from both the leaf disc and internodal explants from 10 to 15 days of incubation. A broad range of dissimilarity was observed in rate of callus formation as well as nature of callus.

At lower concentration of NAA and BAP combination $(0.5 \mathrm{mg} / \mathrm{l} \mathrm{NAA}+0.1 \mathrm{mg} / \mathrm{l} \mathrm{BAP})$ both the leaf and internodal explants

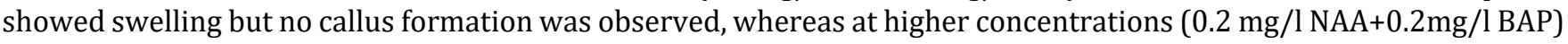
callus formation was not occurred at all. But at moderate concentrations of NAA in combination with BAP (1.0 mg/l $\mathrm{NAA}+0.1 \mathrm{mg} / \mathrm{l} \mathrm{BAP}$ ), leaf explants produced high intensity, brownish fragile callus which exhibit good performance than low and high concentrations of NAA in combination with BAP. Whereas internodal explants produced yellowish compact to green nodular character of callus on $1.0 \mathrm{mg} / \mathrm{l} \mathrm{NAA}$ and $0.1 \mathrm{mg} / \mathrm{l}$ BAP supplemented medium. Only greenish and organogenic high intensity callus was achieved on $1.5 \mathrm{mg} / \mathrm{l} \mathrm{NAA}+0.2 \mathrm{mg} / \mathrm{l} \mathrm{BAP}$ concentrations from leaf explants.

MS supplemented with 2, 4-D and IAA in combination with BAP was also tested for callus initiation from leaf disc and internodal explants. At lower concentration of 2,4-D in combination with BAP ( $0.5 \mathrm{mg} / \mathrm{l} 2,4$-D+0.1mg/l BAP) also gave rise same results as like as NAA and BAP combination and showed swelling but no callus formation in both leaf disc and internodal explants. At moderate and higher concentrations of 2,4-D in combination with BAP (1.0-2.0 mg/l 2,4-D+0.1$0.2 \mathrm{mg} / \mathrm{l}$ BAP) showed good performance than lower concentrations and observed a wide nature of callus such as light greenish fragile, brownish fragile, light greenish compact, dark greenish compact, dark greenish fragile, cremish white fragile in both explants. At the start of callusing, leaf folding and bulging of internodal was observed and various colours of callus was observed ranging from colourless to yellowish and then light green. Light green colours of callus were turned into dark green after two weeks of incubation.

Undifferentiated and unorganized mass of parenchyma cells formed by the enhancement of parent tissue is known as callus. Callus tissue is seems to be a good potentiality of genetic variability such as somaclonal variation through adventitious shoot formation [31]. Usually callus formation begins at the cutting surface area of the explant and rapidly it covers the whole explant following mitosis division and resulted due to wound reaction or effect of exogenous growth regulator in the medium [30]. Exogenous application of auxin and cytokinin induces callus in various plant species. An intermediate ratio of auxin and cytokinin promotes callus induction, while a high ratio of auxin-to-cytokinin or cytokinin-to-auxin induces root and shoot regeneration, respectively [32]. 
Table 1 Effect of various concentrations of auxins and cytokinins ratio on callus induction from in vitro cultured leaf disc and internodal explants of M. piperita

\begin{tabular}{|c|c|c|c|c|c|c|c|c|}
\hline \multirow{2}{*}{\multicolumn{5}{|c|}{$\begin{array}{c}\text { Plant growth regulators } \\
\text { (mg/l) }\end{array}$}} & \multicolumn{4}{|c|}{ Type of explant } \\
\hline & & & & & \multicolumn{2}{|r|}{ Leaf disc } & \multicolumn{2}{|c|}{ Internode } \\
\hline NAA & 2,4-D & IAA & BAP & Kn & $\begin{array}{l}\text { Intensity of } \\
\text { callus } \\
\text { formation }\end{array}$ & $\begin{array}{l}\text { Texture and Nature } \\
\text { of callus }\end{array}$ & $\begin{array}{l}\text { Intensity of } \\
\text { callus } \\
\text { formation }\end{array}$ & $\begin{array}{l}\text { Texture and Nature } \\
\text { of callus }\end{array}$ \\
\hline 0.5 & - & - & 0.1 & - & - & $\begin{array}{l}\text { Swelling, no callus } \\
\text { formation }\end{array}$ & - & $\begin{array}{l}\text { Swelling, no callus } \\
\text { formation }\end{array}$ \\
\hline 1.0 & - & - & 0.1 & - & ++ & Brownish, fragile & ++ & $\begin{array}{l}\text { Yellowish green, } \\
\text { compact }\end{array}$ \\
\hline 1.5 & - & - & 0.2 & - & +++ & Greenish, organogenic & +++ & Light green, compact \\
\hline 2.0 & - & - & 0.2 & - & - & No callus formation & - & No callus formation \\
\hline 0.5 & - & - & - & 0.1 & - & $\begin{array}{l}\text { Swelling, no callus } \\
\text { formation }\end{array}$ & - & $\begin{array}{l}\text { Swelling, no callus } \\
\text { formation }\end{array}$ \\
\hline 1.0 & - & - & - & 0.1 & ++ & Light green, compact & ++ & Light brown, fragile \\
\hline 1.5 & - & - & - & 0.2 & + & Light green, fragile & ++ & $\begin{array}{l}\text { Creamish white, } \\
\text { fragile }\end{array}$ \\
\hline 2.0 & - & - & - & 0.2 & - & No callus formation & - & No callus formation \\
\hline- & 0.5 & - & 0.1 & - & - & $\begin{array}{l}\text { Swelling, no callus } \\
\text { formation }\end{array}$ & - & $\begin{array}{l}\text { Swelling, no callus } \\
\text { formation }\end{array}$ \\
\hline- & 1.0 & - & 0.1 & - & + & Light green, fragile & ++ & Brownish, fragile \\
\hline- & 1.5 & - & 0.2 & - & ++ & Light green, compact & + & Dark green, compact \\
\hline- & 2.0 & - & 0.2 & - & ++ & Dark green, fragile & ++ & $\begin{array}{l}\text { Creamish white, } \\
\text { fragile }\end{array}$ \\
\hline- & 1.0 & - & - & 0.1 & + & $\begin{array}{l}\text { Creamish white, } \\
\text { fragile }\end{array}$ & + & $\begin{array}{l}\text { Creamish white, } \\
\text { fragile }\end{array}$ \\
\hline- & 1.5 & - & - & 0.2 & +++ & Dark green, nodular & +++ & Greenish, compact \\
\hline- & 2.0 & - & - & 0.2 & - & No callus formation & - & No callus formation \\
\hline- & - & 1.0 & 0.1 & - & + & Light brown, compact & + & Light brown, fragile \\
\hline- & - & 2.0 & 0.2 & - & - & $\begin{array}{l}\text { Swelling, no callus } \\
\text { formation }\end{array}$ & - & No callus formation \\
\hline- & - & 1.0 & - & 0.1 & + & $\begin{array}{l}\text { Creamish green, } \\
\text { fragile }\end{array}$ & + & $\begin{array}{l}\text { Creamish white, } \\
\text { fragile }\end{array}$ \\
\hline- & - & 2.0 & - & 0.2 & - & $\begin{array}{l}\text { Swelling, no callus } \\
\text { formation }\end{array}$ & - & No callus formation \\
\hline
\end{tabular}

Different combinations of auxin and cytokinin ratio were evaluated for the induction of callus and among them, $1.5 \mathrm{mg} / \mathrm{l}$ $\mathrm{NAA}+0.2 \mathrm{mg} / \mathrm{l}$ BAP combinations showed better response for induction of high frequency greenish and organogenic nature of callus formation. Similar observations were stated in Stevia rebaudiana [33] and Solanum viarum [34]. Hence, Sujana and Naidu [2] reported that $1.0 \mathrm{mg} / \mathrm{l}$ 2, 4-D + $0.5 \mathrm{mg} / \mathrm{l}$ BAP combinations showed best response for induction of greenish organogenic fragile callus in Mentha piperita from leaf explants. It was also reported that MS supplemented NAA and BAP combination produce maximum number of callus formation and highest percentage of shoot proliferation within very short time from leaf [35] and internodal explants [36] in potato. It has also been recommended that naphthalene acetic acid (NAA) is important for callus induction. 


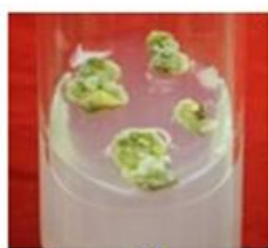

(a)

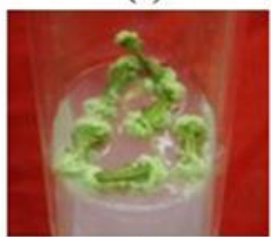

(g)

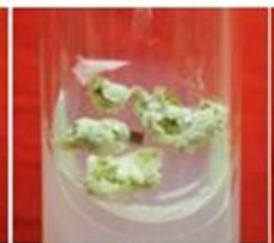

(b)

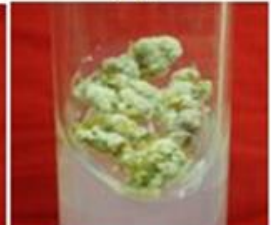

(h)

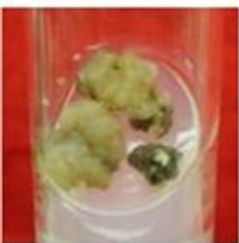

(c)

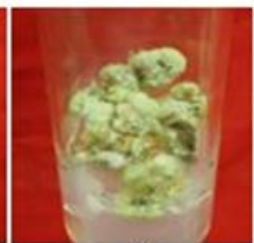

(d)

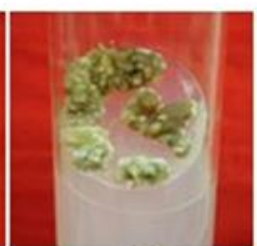

(e)

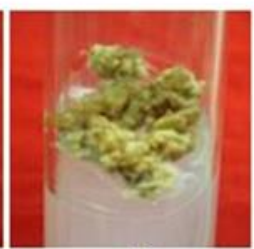

(f)

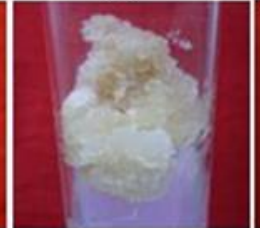

(i)

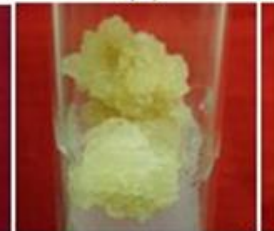

(j)

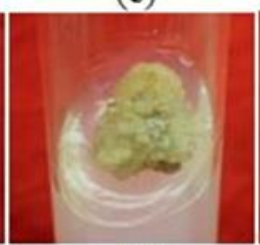

(k)

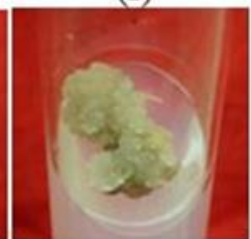

(1)

Figure 2 In vitro callus induction from leaf disc (a-f) and internodal (g-l) explants and nature of different types of callus, $a, b$ and $g, h=2$ weeks after culture, $c, d$ and $i, j=3$ weeks after culture, e, $f$ and $k, l=4$ weeks after culture

\subsection{Effect of NAA, 2, 4-D and IAA in combination with Kn on callus induction from leaf disc and internodal explants}

Leaf disc and internodal explants were also cultured on MS medium supplemented with NAA, 2, 4-D and IAA in combination with $\mathrm{Kn}$ at various concentration $(0.5-2.0 \mathrm{mg} / \mathrm{l})$ for callus induction. Callus induction was observed within 10-15 days of culture from both explants and produced moderate callusing. The leaf and internodal explants showed swelling but no callus was formed at lower concentration of NAA and $\mathrm{Kn}(0.5 \mathrm{mg} / \mathrm{l} \mathrm{NAA}+1.0 \mathrm{mg} / \mathrm{l} \mathrm{Kn})$, whereas at higher concentrations $(0.2 \mathrm{mg} / \mathrm{l} \mathrm{NAA}+0.2 \mathrm{mg} / \mathrm{l} \mathrm{Kn})$ callus formation was not occurred yet. High frequency of callus with different color such as light green, compact, fragile in nature was formed when explants were cultured at moderate concentrations of NAA and Kn combination ranging from 1.0-1.5 mg/l NAA+0.1-0.2 mg/l Kn.

It was observed that callus initiation also accelerate on MS supplemented different auxins such as 2, 4-D and IAA with Kn like cytokinin combined medium. Kn in combination with 2, 4-D or IAA at various concentrations (Table-1) induced profuse intensity of callus formation with different color ranging from whitish to greenish as well as yellow whereas, callus nature was compact, nodular and fragile. Similar response of callusing report was noted in Justicia gendarussa [37], Erythrina variegate [38] and Solanum viarum [34].

\subsection{Plant regeneration from leaf disc derived callus}

Plant regeneration via callus culture requires first, the induction of greenish organogenic and nodular nature of callus. Greenish organogenic and nodular nature of callus is essential for adventitious shoot proliferation and also for other in vitro genetic development including introduction of somaclonal variations and somatic embryogenesis. The source of explant origin and its physiological state are critical factors for organogenic callus induction [39]. In this investigation, green-organogenic and nodular callus was achieved only from leaf disc explant. It was confirms in the present study that the leaf explants of the Mentha piperita showed faster response to induce callus formation than internodal explants. This finding is similar to the investigation of Sujana and Naidu [2], Sridar and Naidu [40], Verma et al., [41], Haque et al., [42], Dhital et al., [43] in Mentha piperita, Solanum nigrum, Crocus species and Potato species. Haque et al., [42] reported that leaf derived callus of potato showed best diameter and weight. Dhital et al., [43] also reported that leaf explants showed higher callus induction frequency compared to the callus induction frequency of internode and petiole explants. On the contrary, this results in contrast with Demeter et al., [44] experiment, who might not achieve callus formation from leaf. This are also differ with Shirin et al., [45] and Huda et al., [46] in Potato species. They reported that, internodal segment is the best as an explants source than leaf for callus induction.

Callus induction was obtained within 10 days of inoculation from the explants on MS medium supplemented with any other auxins (IAA, NAA and 2, 4-D) and cytokinin (BAP/Kn) combination. NAA along with BAP was found to be potent hormone for stimulating callus initiation from leaf explants and green organogenic nodular nature of callus was observed on $1.5 \mathrm{mg} / \mathrm{l} \mathrm{NAA}+0.2 \mathrm{mg} / \mathrm{l}$ BAP concentrations and combination (Table -1 and Figure - 2). 


\subsection{Effect of BAP/Kn alone or/and in combination with IAA / NAA on indirect shoot regeneration from leaf disc callus}

The combination of cytokinin and auxins is necessary for indirect shoot regeneration. What types of organ will be regenerated from undifferentiated callus tissue is determined by the combination of cytokinin to auxin ratio. It was observed that, when callus cultured on media containing high cytokinin to low auxin ratio usually produces maximum number of shoots and minimum number of roots while few shoots and many roots were produced when callus tissue were cultured on media containing low cytokinin to high auxin ratio [32].

Table2 Effect of different cytokinins (BAP/Kn) alone or in combination with IAA/NAA on indirect shoot organogenesis of in vitro derived callus from the leaf explants of Mentha piperita

\begin{tabular}{|c|c|c|c|c|c|c|}
\hline \multicolumn{4}{|c|}{$\begin{array}{l}\text { Plant Growth Regulators } \\
\text { (mg/l) }\end{array}$} & \multirow{2}{*}{$\begin{array}{l}\text { Regeneration } \\
\text { frequency }(\%)\end{array}$} & \multirow{2}{*}{$\begin{array}{l}\text { Mean No. of shoots } \\
\text { per callus }\end{array}$} & \multirow[t]{2}{*}{$\begin{array}{l}\text { Mean shoot length } \\
(\mathrm{cm})\end{array}$} \\
\hline BAP & Kn & IAA & NAA & & & \\
\hline 0.5 & - & - & - & 65 & $1.3 \pm 0.22^{\mathrm{a}}$ & $3.6 \pm 0.11^{\text {def }}$ \\
\hline 1.0 & - & - & - & 70 & $3.1 \pm 0.30^{\mathrm{b}}$ & $3.4 \pm 0.19^{\mathrm{cd}}$ \\
\hline 2.0 & - & - & - & 75 & $3.2 \pm 0.31^{c}$ & $3.0 \pm 0.21^{\mathrm{ab}}$ \\
\hline 3.0 & - & - & - & 78 & $4.6 \pm 0.30^{\mathrm{d}}$ & $2.5 \pm 0.29^{a}$ \\
\hline 1.0 & - & 0.5 & - & 60 & $1.9 \pm 0.49^{c}$ & $1.4 \pm 0.25^{j}$ \\
\hline 2.0 & - & 0.5 & - & 65 & $4.1 \pm 0.30^{\mathrm{d}}$ & $5.1 \pm 0.40^{\mathrm{g}}$ \\
\hline 3.0 & - & 0.5 & - & 72 & $5.3 \pm 0.41^{e}$ & $4.1 \pm 0.31^{\mathrm{f}}$ \\
\hline- & 1.0 & 0.5 & - & 75 & $6.2 \pm 0.32^{f}$ & $5.5 \pm 0.41^{\mathrm{gi}}$ \\
\hline- & 2.0 & 0.5 & - & 80 & $9.1 \pm 0.29 \mathrm{~h}$ & $2.1 \pm 0.74$ def \\
\hline- & 3.0 & 0.5 & - & 85 & $12.0 \pm 0.11^{\mathrm{j}}$ & $4.2 \pm 0.10^{\text {cde }}$ \\
\hline 1.0 & - & - & 0.5 & 85 & $8.9 . \pm 0.21^{\mathrm{i}}$ & $4.8 \pm 0.41 \mathrm{gi}$ \\
\hline 2.0 & - & - & 0.5 & 90 & $15.1 \pm 0.11^{1}$ & $2.9 \pm 0.25^{\mathrm{def}}$ \\
\hline 3.0 & - & - & 0.5 & 82 & $11.9 \pm 0.21^{\mathrm{k}}$ & $2.8 \pm 0.10^{\mathrm{bc}}$ \\
\hline- & 1.0 & - & 0.5 & 70 & $3.7 \pm 0.13^{e}$ & $5.0 \pm 0.38^{\mathrm{ij}}$ \\
\hline- & 2.0 & - & 0.5 & 82 & $7.5 \pm 0.15^{\mathrm{g}}$ & $4.9 \pm 0.15^{\mathrm{g}}$ \\
\hline- & 3.0 & - & 0.5 & 70 & $7.1 \pm 0.21^{\mathrm{h}}$ & $2.1 \pm 0.15^{\mathrm{ef}}$ \\
\hline
\end{tabular}

Data represent means \pm SE followed by different letter(s) within column indicate significant differences according to ANOVA and DMRT test $(\mathrm{P}<$ $0.05)$.

Application of differential growth regulators such as BAP, Kn, IAA and NAA in medium enhance the induction of callus and subsequent differentiation and organogenesis. Well profuse callus derived from young leaf explants was subcultured on fresh MS medium supplemented with different concentrations of BAP or Kn alone or/and in combination with auxins such as IAA or NAA. Shoot buds were emerged on leaf derived callus surface after two weeks of subculture. These authors found that highest rate of shoot regeneration $(90 \%)$ and maximum shoot number $(15.1 \pm 0.11)$ was induced on $2.0 \mathrm{mg} / \mathrm{l} \mathrm{BAP}+0.5 \mathrm{mg} / \mathrm{l} \mathrm{NAA}$. It was observed that increase of cytokinins and auxin combination ratio ranging from $1.0-3.0 \mathrm{mg} / \mathrm{l}$ in the medium resulted gradually increase the proliferation of shoot per culture from regenerated callus. The highest shoot length $(5.5 \pm 0.41 \mathrm{~cm})$ was observed on BAP $(3.0 \mathrm{mg} / \mathrm{l})$ and IAA $(0.5 \mathrm{mg} / \mathrm{l})$ where lowest shoot length $(1.4 \pm 0.25 \mathrm{~cm})$ was recorded on BAP $(1.0 \mathrm{mg} / \mathrm{l})$ and IAA $(0.5 \mathrm{mg} / \mathrm{l})$. Minimum regeneration rate $(60 \%)$ and shoot number $(1.9 \pm 0.49)$ were recorded on BAP $(0.5 \mathrm{mg} / \mathrm{l})$. But when $\mathrm{Kn}$ were used singly then callus showed the poor regeneration performance or no shoots formation at all. In this study, BAP and NAA combination exhibit superior morphogenesis than others (Table-2). In the present investigation, mixing of auxins (NAA or IAA) in combination with cytokinin (BAP or/and Kn) to the culture medium induces the rate of multiple shoot initiation. Similar results were also reported in Mentha piperita [2], Rawolfia tetraphylla [47], Withania somnifera [48], Asteracantha longiflia [49] and Solanum nigrum [40]. Sujana and Naidu [2] were reported in the investigation of indirect plant regeneration from leaf explants of Mentha piperita that, BAP $(2.0 \mathrm{mg} / \mathrm{l})$ alone showed maximum regeneration frequency 
with maximum number of shoot. Sridhar and Naidu [40] were also reported that high rate of shoot proliferation was accomplished by MS supplemented BAP alone in Solanum nigrum. Such type of results were also reported in Vigna radiate [50] and Piper longum [51].

\subsection{In vitro rooting from callus regenerated shoots}

In vitro regenerated healthy shoots from leaf disc derived callus with approximate length of 2.0 to $4.0 \mathrm{~cm}$ were cut and move to MS medium containing various concentrations $(0.5-2.0 \mathrm{mg} / \mathrm{l})$ of IAA and IBA singly. Among the different concentration of auxins tested for rooting in this investigation, IBA showed comparatively better response than the IAA.

Table 3 Effect of IBA and NAA on root formation from in vitro regenerated shoots of Mentha piperita L.

\begin{tabular}{ccccc}
\hline $\begin{array}{c}\text { Plant growth } \\
\text { regulator } \\
\text { (mg/l) }\end{array}$ & $\begin{array}{c}\text { \% of } \\
\text { response }\end{array}$ & $\begin{array}{c}\text { No. of } \\
\text { roots/explants }\end{array}$ & $\begin{array}{c}\text { Root } \\
\text { length/explants } \\
\text { (cm) }\end{array}$ & $\begin{array}{c}\text { Days to } \\
\text { emergence of } \\
\text { roots }\end{array}$ \\
\hline IBA & & & & \\
0.5 & 85 & $13.0 \pm 0.18^{\mathrm{e}}$ & $3.8 \pm 0.21^{\mathrm{b}}$ & $12-15$ \\
1.0 & 90 & $16.3 \pm 0.23^{\mathrm{f}}$ & $3.1 \pm 0.16^{\mathrm{de}}$ & $11-12$ \\
1.5 & 82 & $14.5 \pm 0.28^{\mathrm{c}}$ & $2.5 \pm 0.22^{\mathrm{bc}}$ & $12-14$ \\
2.0 & 80 & $11.6 \pm 0.32^{\mathrm{d}}$ & $1.7 \pm 0.25^{\mathrm{a}}$ & $12-13$ \\
\hline IAA & & & & \\
0.5 & 78 & $6.3 \pm 0.18^{\mathrm{a}}$ & $2.6 \pm 0.26^{\mathrm{c}}$ & $13-14$ \\
1.0 & 80 & $9.5 \pm 0.21^{\mathrm{c}}$ & $3.5 \pm 0.32^{\mathrm{e}}$ & $10-12$ \\
1.5 & 85 & $12.6 \pm 0.31^{\mathrm{g}}$ & $3.0 \pm 0.23^{\mathrm{d}}$ & $12-13$ \\
2.0 & 82 & $7.4 \pm 0.22^{\mathrm{b}}$ & $2.0 \pm 0.16^{\mathrm{f}}$ & $14-15$ \\
\hline
\end{tabular}

Data represent means \pm SE followed by different letter(s) within column indicate significant differences according to ANOVA and DMRT test $(\mathrm{P}<$ 0.05).
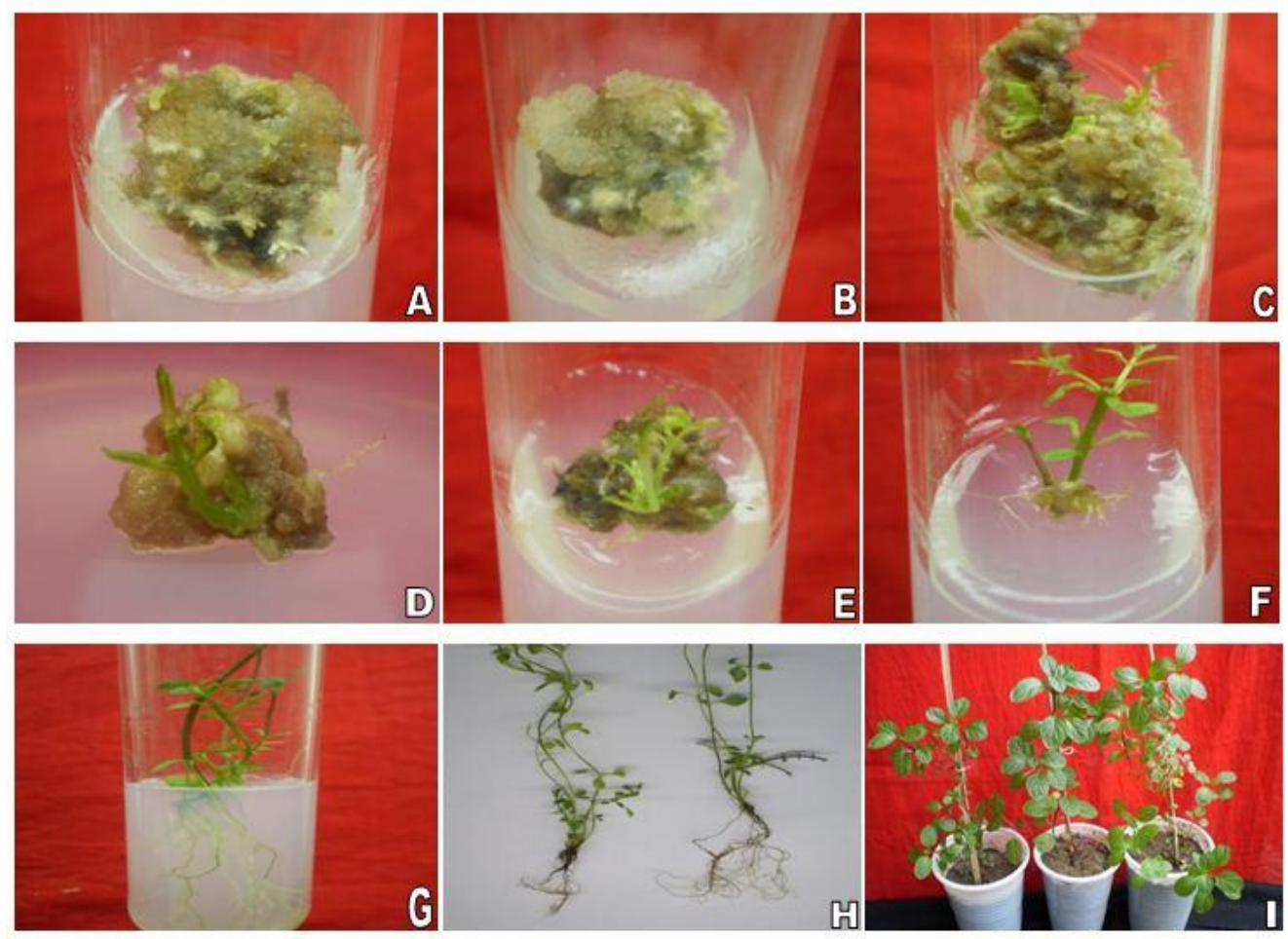

Figure 3 Successive stages of plantlets regeneration via in vitro callus induction from leaf explants and subsequent indirect regeneration of Mentha piperita L. Callus formation and turned into shoot regeneration (A-C); indirect shoot regeneration (D-F); in vitro rooting and hardening (G-I) 
Highest number of roots and root length were observed on IBA supplemented MS medium compared to IAA supplemented medium. High rate (90\%) with highest number of roots (16.3 \pm 0.23$)$ was obtained on $1.0 \mathrm{mg} / \mathrm{l} \mathrm{IBA}$ after 12 days of inoculation. However, the highest root length $(3.9 \pm 0.25)$ was achieved on MS supplemented $0.5 \mathrm{mg} / \mathrm{l}$ IBA. Although IBA showed better response than IAA, however all concentrations of IBA or IAA enhance the root initiation which appeared between 12-15 days of culture. Similar in vitro root initiation was observed in Anisochilus carnosus [52], Centella asiatica [53] and Quisaqualis indica [54]. Similar observations were also reported in Ocimum amaricannum [55] Tylophora asthmatica [56] Mentha viridis [22] Hybanthus enneaspermus [57].

\subsection{Hardening and field establishment}

Well-developed rooted plantlets were transferred to polypots containing sterile soil and vermiculate (1:1) and maintained inside a growth chamber for hardening at room temperature with $75-80 \%$ relative humidity and finally hardened plantlets were move to natural environment at field conditions. Survival rate of rooted plants were $95 \%$ and not found any visible morphological variation or any change of growth characteristics among this regenerated plant when differentiated to the naturally grown plants.

\section{Conclusion}

The described protocol is, simple, reliable, reproducible and highly-efficient. In the present study, leaf disc explant produces a huge amount of adventitious shoots via callus formation. The protocol described here, may shows to be a potential method of propagation of peppermint through callus induction and subsequent plant regeneration from in vitro cultured leaves and internodal explants of Mentha piperita. Despite any visible variation was not showed morphologically in the study, however, there has a good possibility of regenerants may be characterized by somaclonal variation. Such regenerants may prove to be a potential source of somaclonal variants generating to new traits which have a lot of agronomic importance. Moreover, callus induction with maximum regeneration capacity of shoots can also be used for advance experiment such as Agrobacterium mediated genetic transformation systems.

\section{Compliance with ethical standards}

\section{Acknowledgments}

Authors are thankful to Professor Dr. M. Firoz Alam, Department of Botany, University of Rajshahi, Rajshahi-6205, Bangladesh for supervising the research work as well as providing the laboratory facilities during the study.

\section{Disclosure of conflict of interest}

We declare that there are no conflicts of interest in connection with this paper.

\section{References}

[1] Islam ATMR, Islam MM and Alam MF. (2017). Rapid in vitro clonal propagation of herbal spice, Mentha piperita L. using shoot tip and nodal explants. Research in Plant Sciences, 5(1), 43-50.

[2] Sujana P and Naidu CV. (2011). Indirect plant regeneration from leaf explants of Mentha piperita (L.)- An important multipurpose medicinal plant. Journal of Phytology, 3(5), 19-22.

[3] Tucker AO. (1992). The truth about mints. Herb Companion, 4, 51-52.

[4] Sarwar S, Zia M, Rehman RU, Fatima Z, Sial RA and Chaudhary MF. (2009). In vitro direct regeneration in mint from different explants on half strength MS medium. African Journal of Biotechnology, 8(18), 4667 - 4671.

[5] Foster S. (1996). Peppermint: Mentha piperita. American Botanical Council- Botantical Series, 306, 3-8.

[6] Hori M. (1999). Antifeeding, settling inhibitory and toxic activities of labiate essential oils against the green peach aphid, Myzus persicae (Sulzer) (Homoptera: Aphididae). Applied Entomology and Zoology, 34(1), 113-118.

[7] Juergens UR, Stober M and Vetter H. (1998). The anti-inflammatory activity of L-menthol compared to mint oil in human monocytes in vitro: a novel perspective for its therapeutic use in inflammatory diseases. Eur. J. Med. Res., 3(12), 539-545. 
[8] Ali MA, Saleem M, Ahmad W, Parvez M and Yamdagni R. (2002). A chlorinated monoterpene, ketone, acylated $\beta$ sitosterol glycosides and a flavanone glycoside from Mentha longifolia (Lamiaceae). Phytochemistry, 59(8), 889895.

[9] Blumenthal M, Brusse WR, Goldberg A, Gruenwald J, Hall T, Riggins CW and Rister RS. (1998).The complete German commission E monographs: therapeutic guide to herbal medicines, Austin, TX/Boston, MA, American Botanical Council/Integrative Medicine Communications, 136-138.

[10] Veronese P, Li X, Niu X, Weller SC, Bressan RA and Hasegawa PM. (2001). Bioengineering mint crop improvement. Plant Cell Tissue and Organ Culture, 64(2), 133-144.

[11] Jullien F, Diemer F, Colson M and Faure O. (1998). An optimising protocol for protoplast regeneration of three peppermint cultivars (Mentha piperita). Plant Cell Tissue and Organ Culture, 54(3), 153-159

[12] Kumlay AM and Ercisli S. (2015). Callus induction, shoot proliferation and root regeneration of potato (Solanum tuberosum L.) stem node and leaf explants under long day conditions. Biotechnology \& Biotechnological Equipment, 29(6), 1075-1084.

[13] Ghanti K, Kaviraj CP, Venugopal RB, Jabeen FTZ and Rao S. (2004). Rapid Regeneration of Mentha piperita L. from shoot tip and nodal explants. Indian Journal of Biotechnology, 3(4), 594-598.

[14] Sunandakumari C, Martin KP, Chithra M, Sini S and Madhusoodanan PV. (2004). Rapid axillary bud proliferation and ex vitro rooting of herbal spice, Mentha piperita L. Indian Journal of Biotechnology, 3(1),108-112.

[15] Wang X, Gao Z, Wang Y, Bressan RA, Weller SC and Li X. (2009). Highly efficient in vitro adventitious shoot regeneration of peppermint (Mentha x piperita L.) using internodal explants. In Vitro Cellular \& Developmental Biology - Plant, 45(4), 435-440.

[16] Vasile L, Maria Z, Simona V and Eliza A. (2011). Use of nodal explants in "in vitro" micropropagation of Mentha piperita L. Fascicula Protecţia Mediului, 16, 247-251.

[17] Mehta J, Naruka R, Sain M, Dwivedi A, Sharma D and Mirza J. (2012). An efficient protocol for clonal micropropagation of Mentha piperita L. (Peppermint). Asian Journal of Plant Science and Research, 2 (4), 518523.

[18] Bolouk SG, Kazemitabar SKA and Sinaki JM. (2013). In vitro Culture of the Peppermint Plant (Mentha piperita) without the use of Hormones. International Journal of Agriculture and Crop Sciences, 6(18), 1279-1283.

[19] Van Eck JM, Kitto SL. (1992). Regeneration of peppermint and orange mint from leaf disks. Plant Cell Tissue and Organ Culture, 30(1), 41-49.

[20] Sato H, Enomoto S, Oka S, Hosomi K and Ito Y. (1993). Plant regeneration from protoplasts of peppermint (Mentha piperita L.). Plant Cell Reports, 12(10), 546-550.

[21] Caissard JC, Faure 0, Jullien F, Colson M and Perrin A. (1996). A direct regeneration in vitro and transient GUS expression in Mentha piperita. Plant Cell Reports, 16(1), 67-70.

[22] David RH and Arockiasamy DI. (2008). In vitro Propagation of Mentha viridis L. from nodal and shoot tip explants. Plant Tissue Culture and Biotechnology 18(1), 1-6.

[23] Senthil K and Kamraj M. (2012). Direct shoot regeneration from internodal explants of Mentha viridis L. International Journal of Pharmaceutical Sciences and Research, 3(4), 1101-1103.

[24] Rahman MM, Ankhi UR and Biswas A. (2013). Micropropagation of Mentha viridis L.: An aromatic medicinal plant. International Journal of Pharmacy \& Life Sciences, 4(9), 2926-2930.

[25] Ozdemir FA. (2017). Effects of 6-benzylaminopurine and $\alpha$-naphthalene acetic acid on micropropagation from ten days old cotyledon nodes of Mentha spicata subsp. Spicat. Romanian Biotechnological Letters, 22(3), 1255412559.

[26] Fadel D, Kintzios S, Economou SA, Moschopoulou G and Constantinidou HA. (2010). Effect of different strength of medium on organogenesis, phenolic accumulation and antioxidant activity of spearmint (Mentha spicata L.) The Open Horticulture Journal, 3(1), 31-35.

[27] Murashige T and Skoog FA. (1962). Revised medium for rapid growth and bioassays with tobacco tissue cultures. Physiologia Plantarum, 15(3), 473-497.

[28] Lane WD. (1978). Regeneration of apple plants from shoot meristem tips. Plant Science Letters, 16(2-3), 337342 . 
[29] Kumar V, Rashmi D and Banerjee M. (2014). Callus induction and plant regeneration in Solanum tuberosum L. cultivars (Kufri Chipsona 3 and MP-97/644) via leaf explants. International Research Journal of Biological Sciences, 3(6), 66-72.

[30] Martin K. (2002). Rapid propagation of Holostemma adakudien Schult- A rare medicinal plant through axillary bud multiplication and indirect organogenesis. Plant Cell Reports, 21(2), 112-117.

[31] Dodds JH and Roberts LW. (1982). Experiments in plant tissue culture. Cambridge University Press, London, 27.

[32] Skoog F and Miller C. (1957). Chemical regulation of growth and organ formation in plant tissue cultured in vitro. Symposia of the Society for Experimental Biology, 11, 118-130.

[33] Preethi M, Sridhar TM and Naidu CV. (2011). Efficient protocol for indirect shoot regeneration from leaf explants of Stevia rebaudiana (Bert.) - An important calorie free biosweetner. Journal of Phytology, 3(5), 56-60.

[34] Mahadev MD, Panathula CS and Naidu CV. (2014). Efficient protocol for in vitro callus induction and indirect plant regeneration of Solanum viarum (Dunal) - An important anticancer medicinal plant. Int. J. Med. Arom. Plants, 4(2), 117-123.

[35] Yasmin S, Nasiruddin KM, Begum R and Talukder SK. (2003). Regeneration and establishment of potato plantlet through callus formation with BAP and NAA. Asian Journal of Plant Sciences, 2(12), 936-940.

[36] Nasrin S, Hossain MM, Khatun AM, Alam MF and Mondal MRK. (2003). Induction and evaluation of somaclonal variation in potato (Solanum tuberosum L.). Journal of Biological Sciences, 3(2), 183-190.

[37] Agastian P, Williams L and Ignacimuthu S. (2006). In vitro propagation of Justicia gendarussa Burm. F. - A medicinal plant. Indian Journal of Biotechnology, 5(2), 246-248.

[38] Shasthree T, Madhavi S and Mallaiah B. (2009). Regeneration of plantlets of Erythrina variegate (L.) by organogenesis. Research Journal of Biotechnology, 4(3), 30-37.

[39] Harms CT, Baktir I and Oertli JJ. (1983). Clonal propagation in vitro of red beet (Beta vulgaris ssp) by multiple adventitious shoot formation. Plant Cell Tissue and Organ Culture, 2(2), 93-102.

[40] Sridhar TM and Naidu CV. (2011). An efficient callus induction and plant regeneration of Solanum nigrum (L.)An important antiulcer medicinal plant. Journal of Phytology, 3(5), 23-28.

[41] Verma SK, Das AK, Cingoz GS, Uslu E and Gurel E. (2016). Influence of nutrient media on callus induction, somatic embryogenesis and plant regeneration in selected Turkish crocus species. Biotechnology Reports, 10(C), 66-77.

[42] Haque AU, Samad MA and Shapla TL. (2009). In vitro callus initiation and regeneration of potato. Bangladesh Journal of Agricultural Research, 34(3), 449-456.

[43] Dhital SP, Lim HT and Manandhar HK. (2011). Direct and efficient plant regeneration from different explant sources of potato cultivars as influenced by plant growth regulators. Nepal Journal of Science and Technology, $12,1-6$.

[44] Demeter Z, Surányi G, Molnár VA, Sramkó G, Beyer D, Kónya Z, Vasas G, Márta M and Máthé C. (2010). Somatic embryogenesis and regeneration from shoot primordia of Crocus heuffelianus. Plant Cell Tissue Organ Culture, $100(3), 349-353$.

[45] Shirin F, Hossain M, Kabir MF, Roy M and Sarker SR. (2017). Callus induction and plant regeneration from internodal and leaf explants of potato (Solanum tuberosum L.) cultivars. World Journal of Agricaltural Sciences, $3(1), 1-6$.

[46] Huda MS, Hossain MM, Haq MZ, Zamal SS and Karim MR. (2013). Effect of explants on callus formation of potato. Eco friendly Agril. J., 6(8), 146 - 149.

[47] Ghosh KC, Banerjee N. (2003). Influence of plant growth regulators on micropropagation of Rauwolfia tetraphylla (L.). Phytomorphology: An International Journal of Plant Morphology, 53(1), 11-19.

[48] Kannan P, Ebenzer G, Dayanadan P, Abraham GC and Ignacimuthu S. (2005). Large scale production of Withania somnifera (L.). Dunal using in vitro techniques. Phytomorphology: An International Journal of Plant Morphology, 55(3), 259-266.

[49] Panigrahi J, Behere M, Maharana S and Mishra RR. (2007). Bimolecular changes during in vitro organogenesis of Asteracantha longifolia (L.) Nees - A medicinal herb. Indian journal of experimental biology, 45(10), 911-919. 
[50] Rao S, Patil P and Kaviraj CP. (2005). Callus induction and organogenesis from various explants in Vigna radiate (L.). Indian Journal of Biotechnology, 4(4), 556-560.

[51] Bhat SR, Chandel KPS and Malik SK. (1995). Plant regeneration from various explants of cultivated Piper species. Plant Cell Reports, 14(6), 398-402

[52] Jayachandran R. (2004). In vitro culture root formation in Anisochilus carnosus. Journal of Swamy Botany. Club, 21, 27-30.

[53] Panathula CS, Mahadev MD and Naidu CV. (2014). Effect of different carbohydrates on in vitro plant regeneration of Centella asiatica (L.) -An important anti-jaundice medicinal plant. International Journal of Medicinal and Aromatic Plants, 4(1), 41-47.

[54] Poornima D and Shivamurthy GR. (1998). Root formation in Quisqualis indica (L.). Journal of Swamy Botany. Club, 22, 37-38.

[55] Pathnaik SK and Chand PK. (1996). In vitro propagation of the medicinal herbs Ocimum americanum L. syn. O. canum Sims. (Hoary basil) and Ocimum sanctum L. (holy basil). Plant Cell Reports, 15(11), 846-860.

[56] Mukundan U, Sivaram U and Kumar A (2002). Micropropagation of Tylophora ashumatica and Uararia picta. Plant Cell. Biotech. and Mol. Biol., 3(1\&2), 73-76.

[57] Natarajan E, Arockiasamy D and John BS. (1999). Regeneration of plantlets from the callus of stem explants of Hybabanthes enneaspermus (L.) F. Muell. Plant Tissue Culture, 9, 167-172.

\section{How to cite this article}

Islam ATMR and Alam MF. (2018). In vitro callus induction and indirect organogenesis of Mentha piperita (L.) - an aromatic medicinal plant. GSC Biological and Pharmaceutical Sciences, 4(3), 49-60. 